\title{
Frontières
}

\section{Bibliographie indicative sur la prévention du suicide}

Volume 21, numéro 1, automne 2008

Prévenir le suicide

URI : https://id.erudit.org/iderudit/037893ar

DOI : https://doi.org/10.7202/037893ar

Aller au sommaire du numéro

Éditeur(s)

Université du Québec à Montréal

ISSN

1180-3479 (imprimé)

1916-0976 (numérique)

Découvrir la revue

Citer ce document

(2008). Bibliographie indicative sur la prévention du suicide. Frontières, 21(1),

147-148. https://doi.org/10.7202/037893ar d'utilisation que vous pouvez consulter en ligne.

https://apropos.erudit.org/fr/usagers/politique-dutilisation/ 


\section{BIBLIOGRAPHIE INDICATIVE SUR LA PRÉVENTION DU SUICIDE}

\section{ADOLESCENTS}

ASELTINE, R. H., SCHILLING, E. A., JAMES, A. GLANOVSKY, J. L. et D. JACOBS (2009). «Age variability in the association between heavy episodic drinking and adolescent suicide attempts: findings from a large-scale, school-based screening program ", Journal of American Academy of Child and Adolescent Psychiatry, vol. 48, n 3, p. 262-270.

BRENT, D. A., EMSLIE, G. J., CLARKE, G. N., ASARNOW, J., SPIRITO, A., RITZ, L., VITIELLO, B., IYENGAR, S., BIRMAHER, B., RYAN, N. D., ZELAZNY, J., ONORATO, M., KENNARD, B., MAYES, T. L., DEBAR, L. L., MCCRACKEN, J. T., STROBER, M., SUDDATH, R., LEONARD, H., PORTA, G. et M. B. KELLER (2009). «Predictors of spontaneous and systematically assessed suicidal adverse events in the treatment of SSRI-resistant depression in adolescents (TORDIA) study ", American Journal of Psychiatry, in press.

BURSZTEIN, C. et A. APTER (2009). «Adolescent suicide ", Current Opinion in Psychiatry, vol. 22, $\mathrm{n}^{\circ} 1$, p. 1-6.

KING, C. A. et A. C. KRAMER (2008). "Intervention research with youths at elevated risk for suicide: meeting the ethical and regulatory challenges of informed consent and assent ", Suicide and LifeThreatening Behavior, vol. 38, n 5, p. 486-497.

RESCH, F., PARZER, P. et R. BRUNNER (2008). «Selfmutilation and suicidal behaviour in children and adolescents: prevalence and psychosocial correlates: results of the BELLA study ", European Child and Adolescent Psychiatry, 17 (Suppl. 1), p. 92-98.

\section{AÎNÉS}

SHAH, A. (2008). "A cross-national study of the relationship between elderly suicide rates and urbanization", Suicide and Life-Threatening Behavior, vol. 38, n 6 , p. 714-719.

\section{FEMMES}

ALIVERDINIA, A. et W.A. PRIDEMORE (2009). «Women's fatalistic suicide in Iran: a partial test of Durkheim in an Islamic republic», Violence Against Women, in press.

USALL, J., PINTO-MEZA, A., FERNANDEZ, A., GRAAF, R. D., DEMYTTENAERE, K., ALONSO, J., GIROLAMO, G. D., LEPINE, J. P., KOVESS, V. et J. M. HARO (2009). "Suicide ideation across reproductive life cycle of women. Results from a European epidemiological study ", Journal of Affective Disorders, in press.

\section{PRÉVENTION}

CARDELL, R., BRATCHER, K. S. et P. QUINNETT (2009). "Revisiting "suicide proofing" an inpatient unit through environmental safeguards: a review ", Perspectives in Psychiatric Care, vol. 45, no 1, p. 36-44.

CHAGNON, F. et B. MISHARA (dir.) (2004). Évaluation de programmes en prévention du suicide, Québec, Presses de I'Université du Québec et Paris, Éditions EDK.

GILAT, I. et G. SHAHAR (2009). «Suicide prevention by online support groups: an action theorybased model of emotional first aid ", Archives of Suicide Research, vol. 13, n 1, p. 52-63.
HAWTON, K., RATNAYEKE, L., SIMKIN, S., HARRISS, L. et V. SCOTT (2009). "Evaluation of acceptability and use of lockable storage devices for pesticides in Sri Lanka that might assist in prevention of self-poisoning", BMC Public Health, 9.

MISHARA, B. et M. TOUSIGANT (2004). Comprendre le suicide, Montréal, Presses de I'Université de Montréal.

\section{INTERVENTION, THÉRAPIE ET TRAITEMENT}

BALL, L.R. (2007). Suicide Risk Assessment: Practical Strategies and Tools for Joint Commission Compliance, Marblehead, MA, HCPro.

BARBUI, C., ESPOSITO, E. et A. CIPRIANI (2009). "Selective serotonin reuptake inhibitors and risk of suicide: a systematic review of observational studies ", CMAJ, vol. 180, n³ 3, p. 291-297.

CUTCLIFF, J. R. et C. STEVENSON (2007). Care of the Suicidal Person, Toronto, Churchill Livingstone-Elsevier.

ISACSSON, G., HOLMGREN, A., OSBY, U. et J. AHLNER (2009). «Decrease in suicide among the individuals treated with antidepressants: a controlled study of antidepressants in suicide, Sweden 19952005 ", Acta Psychiatrica Scandinavica, in press.

LAFLEUR, C. et M. SÉGUIN (2008). Intervenir en situation de crise suicidaire. L'entrevue clinique, Québec, Les Presses de I'Université Laval.

LEONG, F. T. L. et M. M. LEACH (2008). Suicide Among Racial and Ethnic Minority Groups. Theory, Research and Practice, New York, Routledge.

ZISOOK, S., TRIVEDI, M. H., WARDEN, D., LEBOWITZ, B., THASE, M. E., STEWART, J. W., MOUTIER, C., FAVA, M., WISNIEWSKI, S. R., LUTHER, J. et A. J. RUSH (2009). "Clinical correlates of the worsening or emergence of suicidal ideation during SSRI treatment of depression: an examination of citalopram in the STAR*D study ", Journal of Affective Disorders, in press.

\section{ÉVALUATION}

HANBURY, A., WALLACE, L. et M. CLARK (2008), "Use of a time series design to test effectiveness of a theory-based intervention targeting adherence of health professionals to a clinical guideline ", British Journal of Health Psychology, in press.

\section{ÉTHIQUE ET ATTITUDE}

BRAUN, W. (2008). "Sallekhana: the ethicality and legality of religious suicide by starvation in the Jain religious community", Medicine and Law, vol. 27, nº 4, p. 913-924.

\section{SUICIDOLOGIE (GÉNÉRAL)}

FAZEL, S., CARTWRIGHT, J., NORMAN-NOTT, A. et K. HAWTON (2008). "Suicide in prisoners: a systematic review of risk factors", Journal of Clinical Psychiatry, 69, p. 1721-1731.

HASLEY, J. P., GHOSH, B., HUGGINS, J., BELL, M. R., ADLER, L. E. et A. L. SHROYER (2008). «A review of "suicidal intent" within the existing suicide literature", Suicide and Life-Threatening Behavior, vol. 38, n 5, p. 576-591.

HEWITT, J. (2009). « Rational suicide: philosophical perspectives on schizophrenia ", Medicine, Health Care and Philosophy, in press.

LAKEMAN, R. et M. FITZGERALD (2009). «Ethical suicide research: a survey of researchers ", International Journal of Mental Health Nursing, vol. 8, $\mathrm{n}^{\circ} 1, \mathrm{p} .10-17$.
LAKEMAN, R. et M. FITZGERALD (2008). "How people live with or get over being suicidal: a review of qualitative studies", Journal of Advanced Nursing, vol. 64, n² 2, p. 114-126.

MARUSIC, A. et A. VIDETIC (2008). «Suicide risk: where, why and how is it generated?" Psychiatria Danubina, vol. 20, n 3, p. 262-268.

MORRISON, R. et R. C. O'CONNOR (2008). «A systematic review of the relationship between rumination and suicidality ", Suicide and LifeThreatening Behavior, vol. 38, n 5, p. 523-538.

NOCK, M. K. (2008). «Actions speak louder than words: an elaborated theoretical model of the social functions of self-injury and other harmful behaviors", Applied and Preventive Psychology, vol. $12, n^{\circ} 4$, p. 159-168

\section{ÉPIDÉMIOLOGIE ET STATISTIQUES}

ELNOUR, A. A. et J. HARRISON (2009). "Suicide decline in Australia: where did the cases go?", Australian and New Zealand Journal of Public Health, vol. 33, n 1, p. 67-69.

\section{PSYCHOPATHOLOGIE ET SANTÉ MENTALE}

AZORIN, J. M., KALADJIAN, A., ADIDA, M., HANTOUCHE, E., HAMEG, A., LANCRENON, S. et H. S. AKISKAL (2009). «Risk factors associated with lifetime suicide attempts in bipolar I patients: findings from a French National Cohort», Comprehensive Psychiatry, vol. 50, n² 2, p. 115-120.

BLASCO-FONTECILLA, H., BACA-GARCIA, E., DERVIC, K., PEREZ-RODRIGUEZ, M. M., SAIZGONZALEZ, M. D., SAIZ-RUIZ, J., OQUENDO, M. A. et J. DE LEON (2008). "Severity of personality disorders and suicide attempt ", Acta Psychiatrica Scandinavica, in press.

BRADEN, J. B. et M. D. SULLIVAN (2008). «Suicidal thoughts and behavior among adults with selfreported pain conditions in the national comorbidity survey replication ", The Journal of Pain, vol. 9, n²12, p. 1106-1115.

CARLBORG, A., JOKINEN, J., JONSSON, E. G., NORDSTROM, A. L. et P. NORDSTROM (2008). "Long-term suicide risk in schizophrenia spectrum psychoses: survival analysis by gender ", Archives of Suicide Research, vol. 12, n 4, p. 347-351.

COUGLE, J. R., KEOUGH, M. E., RICCARDI, C. J. et N. SACHS-ERICSSON (2009). "Anxiety disorders and suicidality in the National Comorbidity Survey-Replication », Journal of Psychiatric Research, in press.

GARCIA-AMADOR, M., COLOM, F., VALENTI, M., HORGA, G. et E. VIETA (2008). "Suicide risk in rapid cycling bipolar patients ", Journal of Affective Disorders, in press.

HANBURY, A., WALLACE, L. et M. CLARK (2008). "Use of a time series design to test effectiveness of a theory-based intervention targeting adherence of health professionals to a clinical guideline", British Journal of Health Psychology, in press.

HARNED, M. S., CHAPMAN, A. L., DEXTERMAZZA, E. T., MURRAY, A., COMTOIS, K. A. et M. M. LINEHAN (2008). «Treating co-occurring Axis I disorders in recurrently suicidal women with borderline personality disorder : a 2-year randomized trial of dialectical behavior therapy versus community treatment by experts ", Journal of Consulting Psychology, vol. 76, n 6, p. 1068-1075.

HOVANESIAN, S., ISAKOV, I et K. L. CERVELLIONE (2009). «Defense mechanisms and suicide risk in major depression ", Archives of Suicide Research, vol. $13, n^{\circ} 1$, p. 74-86. 
NEVES, F. S., MALLOY-DINIZ, L. F. et H. CORREA (2008). "Suicidal behavior in bipolar disorder: What is the influence of psychiatric comorbidities? ", Journal of Clinical of Psychiatry, in press.

SHER, L., OQUENDO, M. A., RICHARDSONVEJLGAARD, R., MAKHIJA, N. M., POSNER, K., MANN, J. J. et B. H. STANLEY (2009). «Effect of acute alcohol use on the lethality of suicide attempts in patients with mood disorders ", Journal of Psychiatric Research, in press.

TIDEMALM, D., LANGSTROM, N., LICHTENSTEIN, P. et B. RUNESON (2008). « Risk of suicide after suicide attempt according to coexisting psychiatric disorder: Swedish cohort study with long term follow-up ", BMJ, 337, p. a2205.

\section{AUTRES FACTEURS DE RISQUE}

BAUD, P., PERROUD, N., COURTET, P., JAUSSENT, I., RELECOM, C., JOLLANT, F. et A. MALAFOSSE (2009). «Modulation of anger control in suicide attempters by TPH-1 ", Genes, Brain and Behavior, vol. 8, n० 1, p. 97-100.

BJORK PETERSEN, C., GRONBAEK, M. N., BUSSEY RASK, M., NIELSEN, B. et A. SOGAARD NIELSEN (2008). "Suicidal behaviour among alcoholdependent Danes attending outpatient treatment ", Nordic Journal of Psychiatry, p. 1-8.

FAZAA, N. et S. PAGE (2009). «Personality style and impulsivity as determinants of suicidal subgroups ", Archives of Suicide Research, vol. 13, $n^{\circ} 1$, p. 31-45.

O'DONNELL, M. L., CREAMER, M., ELLIOTT, P., BRYANT, R., MCFARLANE, A. et D. SILOVE (2009). «Prior trauma and psychiatric history as risk factors for intentional and unintentional injury in Australia ", The Journal of Trauma, vol. 66, $n^{\circ} 2$, p. 470-476.

PEDERSEN, W. et T. VON SOEST (2009). «Smoking, nicotine dependence and mental health among young adults: a 13-year population-based longitudinal study", Addiction, vol. 104, n 1, p. 129 137.

RIALA, K., TAANILA, A., HAKKO, H. et P. RASANEN (2009). "Longitudinal smoking habits as risk factors for early-onset and repetitive suicide attempts: the Northern Finland 1966 Birth Cohort study ", Annals of Epidemiology, in press.

SORENSEN, H. J., MORTENSEN, E. L., WANG, A. G., JUEL, K., SILVERTON, L. et S. A. MEDNICK (2009). "Suicide and mental illness in parents and risk of suicide in offspring: A birth cohort study", Social Psychiatry and Psychiatric Epidemiology, in press.

STIRN, A. et A. HINZ (2008). «Tattoos, body piercings, and self-injury: is there a connection? Investigations on a core group of participants practicing body modification ", Psychotherapy Research, vol. 18, n³, p. 326-333.

WYDER, M., WARD, P. et D. DE LEO (2009). «Separation as a suicide risk factor ", Journal of Affective Disorders, in press.

\section{MÉDIA}

FU, K. W. et P. S. YIP (2008). "Changes in reporting of suicide news after the promotion of the WHO media recommendations", Suicide and LifeThreatening Behavior, vol. 38, n 5, p. 631-636.

\section{NOUVELLES PARUTIONS - ÉTUDES SUR LA MORT}

Serge Gariépy, bibliothécaire de référence, Bibliothèque centrale, UQAM.

BEAUTHÉAC-BOUCHART, Nadine (2008). Hommes et femmes face au deuil: regards croisés sur le chagrin, Paris, Albin Michel.

BÉLAND, Jean-Pierre (2008). Mourir dans la dignité? Soins palliatifs ou suicide assisté, un choix de société, Québec, Presses de I'Université Laval.

BOISVENU, Pierre-Hugues (2008). Survivre à l'innommable et reprendre le pouvoir sur sa vie, Montréal, Éditions de l'Homme.

BROHM, Jean-Marie (2008). Figures de la mort: perspectives critiques, Paris, Beauchesne.

CARLOS, France (2008). Le deuil animalier, SaintConstant, Broquet.

CROS, Michèle (2008). Déjouer la mort en Afrique: or, orphelins, fantômes, trophées et fétiches, Paris, L'Harmattan.

JACQUES, Josée (2008). Le milieu funéraire démystifié, Outremont, Quebecor.

KEIRSE, Manu (2008). Faire son deuil, vivre un chagrin: un guide pour les proches et les professionnels, Bruxelles, De Boeck.

KENTISH-BARNES, Nancy (2008). Mourir à I'hôpital: décisions de fin de vie en réanimation, Paris, Seuil.

LAFONTAINE, Céline (2008). La société post-mortelle: la mort, l'individu et le lien social à l'ère des technosciences, Paris, Seuil.
LAPLANTE, Francine et Michel LEBOEUF (2008). Jusqu'au bout de ta courte vie: accompagner son enfant malade vers la mort et y survivre, Montréal, Éditions La Presse.

LÉGER, Pierre (2008). La mort et l'au-delà, Montréal, Novalis.

LEGROS, Patrick et Carine HERBÉ (2006). La mort au quotidien: contribution à une sociologie de I'imaginaire de la mort et du deuil, RamonvilleSaint-Agne, Erès.

MAUGEIN, Patrick (2006). Ouï-dire sur la mort, Paris, J.-C. Gawsewitch.

MONBOURQUETTE, Jean (2008). La mort, ça s'attrape?, Ottawa, Novalis.

MYTTENAERE, Chantal (2007). Panser le deuil, Paris, Éditions de l'Hèbe.

RAY, Ruth E. (2008). Endnotes: An Intimate Look at the End of Life, New York, Columbia University Press.

ROGERS, J. Earl (2007). The Art of Grief. The Use of Expressive Arts in a Grief Support Group, New York, Routledge.

THIEL, Marie-Jo (2008). Les rites autour du mourir, Strasbourg, Presses universitaires de Strasbourg.

WEE, Bee et Nic Hughes (2007). Education in Palliative Care: Building a Culture of Learning, Oxford, Oxford University Press.

WEINSTEIN, Jeremy (2008). Working with Loss, Death and Bereavement: A Guide for Social Workers, Thousand Oaks (CA), Sage Publications.

ZECH, Emmanuelle (2007). Psychologie du deuil: impact et processus d'adaptation au décès d'un proche, Wavre, Belgique, Mardaga.

\section{APPEL D'ARTICLES}

\author{
Sur les thèmes suivants : \\ Résilience et deuil \\ Enquêtes sur le cadavre
}

Avant de soumettre votre article, veuillez consulter le protocole de rédaction de la revue Frontières disponible à l'adresse suivante: www.frontieres.uqam.ca/pdf/protocole-de-redaction.pdf

Faites-nous ensuite parvenir votre texte à : frontieres@uqam.ca

Les articles soumis seront évalués de façon anonyme par un comité scientifique externe. 